\section{The Department of Geology, University of Liverpool.}

New Gift from Sir William Herdman.

$\mathrm{N}_{\mathrm{N}}$ Tuesday, May I5, the Council of the University of Liverpool accepted a gift of $20,000 l$, from Sir William A. Herdman for the provision of a new building for the Department of Geology. Sir William Herdman desired his gift to be associated with the memory of the late Lady Herdman, and that the new laboratories should bear her name. It will be recollected that, after urging for many years the desirability of the foundation of a chair of geology in the University, Sir William Herdman, in company with Lady Herdman, eventually offered the University the sum of $10,000 l$. for the purpose of endowing the George Herdman chair in memory of their only son, who was killed in action in I9I6.

Largely through the foresight of Sir William Herdman and Sir Alfred Dale, the late Vice-Chancellor of the University, accommodation had been reserved in an extension of the Zoology Department. The Geological Department thus consisted of two floors and a library, but the new professor had the great advantage of dividing up the shell of the building into suitable laboratories and of equipping them for special needs. Sir William Herdman had been securing for many years valuable collections and books in preparation for the future department. The equipment of the laboratories, was assisted very materially by a gift of $2000 l$. from Mrs. and Miss Holt, relatives of Lady Herdman, long well known for their great and numerous benefactions to the University. Many other donations towards equipment and the cost of purchasing collections, etc., were made by Sir William and Lady Herdman in the succeeding years, and several students in the Department had reason to be grateful for their kind and practical help.

The School of Geology, founded in I9r 7, has grown rapidly-not unexpected, when it is remembered that Liverpool has long been known for such distinguished amateur geologists as G. H. Morton, C. Mellard Reade, H. C. Beasley, and J. Lomas, and its active Geological Society with a sixty years' record of published work. The accommodation of the Department has for the past three years been insufficient for its needs, and Sir William and Lady Herdman frequently expressed their desire to see the school housed more fitly. Lady Herdman's sudden and lamented death last autumn prevented the new gift being a joint one, but it was a happy thought of Sir William Herdman to associate the names of wife and son with the laboratories and chair respectively.

Apart from this valuable assistance towards the furtherance of geological work, it may be recalled that in 1919 Sir William and Lady Herdman also endowed the chair of oceanography in the University.

\section{University and Educational Intelligence.}

ABERDEEN.-Dr. H. R. Kruyt, professor of physical chemistry in the University of Utrecht, delivered a University lecture on May I4, his subject being "The Electric Charge of the Colloids."

The Students' Gala Week in aid of the Aberdeen Hospitals has realised a nett sum of $4753 l$.

Prof. J. Arthur Thomson has been appointed a member of the committee of inquiry on trawling.

ST. ANDREWS.-Among the names of those on whom the Senatus Academicus has resolved to confer the honorary degree of LL.D. at the graduation ceremonial on July 6 are the following :-Sir William
Henry Hadow, vice-chancellor of the University of Sheffield; Mr. Herbert William Richmond, University lecturer in mathematics in the University of Cambridge, and retiring presiclent of the London Mathematical Society; and Sir Robert Robertson, chief Government chemist, London.

Birmingham.-The Huxley Lecture is to be delivered on Thursday, June 7, 5.30 P.M., at Mason College, by Sir Arthur Keith, who has chosen as his subject "The Origin of the British People."

Dr. H. H. Sampson has been appointed honorary assistant curator of the surgical section of the Pathological Museum, and Mr. J. S. M. Connell, honorary assistant curator of the gynæcological section.

Prof. John Robertson is to represent the University at the meeting of the National Association for the Prevention of Tuberculosis, to be held in Birmingham in July next.

The Ingleby Lectures will be delivered at 4 o'clock on May 30 and June 6 by Dr. H. Black, who will take as his subject "The Investigation of the Alimentary Tract by X-rays." The lectures are open to all medical men.

CAmbridge.-Dr. W. L. H. Duckworth, Jesus College, has been elected as representative of the University on the General Medical Council.

Dr. E. Lloyd Jones, Downing College, has been reelected demonstrator of medicine. An honorary degree of Master of Arts is to be conferred on Dr. J. T. MacCurdy, Corpus Christi College, University lecturer in psychopathology.

DURHAM.-An anonymous donor has presented the capital sum of $12,000 l$. to Armstrong College, Newcastle-upon-Tyne, the interest of which is to be devoted to the establishment of research fellowships and possibly prizes of similar character to the Adams prize at Cambridge, or in such other manner as the Council of the College may decide is best calculated to promote original work in pure and applied science and the humanities.

The Council of the College has decided to proceed immediately with the erection of a permanent library at an estimated cost of some 40,000 . It has long been felt that there is great need of a scholars' library on the north-east coast, and it is hoped that when the new library is built it will form a worthy centre for all students of the district, whether members of the University or not. It is understood that the Unemployment Grants Committee are favourably disposed to consider such a scheme as a work of public utility deserving assistance from public funds.

Edinburgh.-On Wednesday, May I6, Prof. H. R. Kruyt, of the University of Utrecht, delivered a lecture on "The Electric Charge of Colloids"; and on Friday, May r8, Prof. W. de Sitter, of the University of Leyden, lectured on "Problems of Fundamental Astronomy."

LoNDON.-Prof. Leonard Bairstow has been appointed as from September I next to the Zaharoff chair of aviation tenable at the Imperial College of Science and Technology. He has been head of the Aeronautical Department of the National Physical Laboratory, and since 1920 has been professor of aerodynamics at the Imperial College.

Dr. C. L. Boulenger has been appointed as from September I next to the University chair of zoology tenable at Bedford College. Since I922 he has been lecturer in, and temporary head of, the department of zoology at the college. $\mathrm{He}$ is the author of a number of papers on Coelenterata, helminthology,
and other subjects.

Miss B. E. M. Hosgood has been appointed as

NO. 2795 , VOL. I I I 7 
from September I next to the University readership in geography tenable at Bedford College. In r.9r8 she was appointed assistant lecturer in geography at the College, and has been since I920 head of that department.

Dr. John Marshall has been appointed as from September I next to the University readership in mathematics tenable at Bedford College. $\mathrm{He}$ has been junior lecturer in mathematics at University College, Dundee, and senior lecturer in mathematics at University College, Nottingham. Since I920 he has been senior lecturer in mathematics at University College, Swansea.

OxFord.-On May I5 a decree was passed by Convocation authorising the presentation of an address to the Universities of Paris and Strasbourg on the occasion of the celebration of the centenary of the birth of Louis Pasteur.

It has been decided to offer an annual scholarship in chemistry under the will of the late Charles Day Dowling Gibbs.

A prize in natural science has been established by Mrs. Emily Pouiton, in memory of her daughter, Hilda Ainley Walker, open to women members of the Society of Oxford Home-Students.

ThE Ellen Richards Research Prize of Iooo dollars, for 1924 , is being offered for theses by women, based on independent laboratory research. If the prize should not be awarded, a grant may be made under certain conditions. Information respecting the prize, and application forms, are obtainable from Dr. Lilian Welsh, Goucher College, Baltimore, Maryland, U.S.A., or from Mrs. Samuel F. Clarke, Williamstown, Mass., U.S.A.

The Dr. Edith Pechey Phipson post-graduate scholarship, value 100 l. a year for not more than three years, will be awarded in June by the council of the London (Royal Iree Hospital) School of Medicine for Women. The scholarship is open to all medical women, preferably coming from India, or going to work in India, and is for assistance in post-graduate study. The latest date for the receipt of applications (which should be sent to the Warden and Secretary of the School, 8 Hunter Street, W.C.I) is May $3 I$.

THE Board of Education is organising short summer courses of instruction for teachers in technical and evening schools (Form ro5e. U.). Engineering science and electrical engineering are dealt with at Oxford and Birmingham. Both courses commence at Birmingham on July 23 and are concluded (July 28 to August 8) at Oriel College, Oxford. The courses include practical work on heat engines, hydraulics, mechanics, materials, electrical testing, wireless, thermo-electricity and magnetic testing. Building science is divided into two courses, (a) building mechanics and structures and (b) general science and laboratory work, both at Westminster Training College, Horseferry Road, London, S.W.I. Applications to attend these courses, to be obtained and returned through the local Education Authority if the teacher is working under such an authority, must be received by the Board of Education not later than June $I$.

THE Manchester Municipal College of Technology is this year celebrating its " coming of age." It originated in a Mechanics' Institution founded in I824 with the object, common to many similar foundations of the second quarter of the nineteenth century, of " enabling mechanics and artisans to become acquainted with such branches of science as are of practical application in the exercise of their trades." Conceived without much regard to the principles of industrial psychology, the methods employed commonly failed to attract people of the class for whom they were intended, and thirty years after its foundation a vice-president of the Manchester institution remarked, "Nature was as bountiful to the working-class in talent and energy as to the higher classes," but " those for whom this institution was destined did not avail themselves of it," and " until we enforced education upon all classes, Mechanics' Institutions, successful as they might be to some classes, would not produce the great advantage they might otherwise do." The Paris exhibition of I867 having attracted attention to a growing inferiority of English arts and crafts, a cry was again raised for technical education among workmen, and this was echoed by the directors of the Manchester institution, who in their report for I868 approved of " recurring to a system of education the basis of which was prescribed in the original preamble, viz. to instruct the working-classes in the principles of the arts they practise." In 1882 it was converted into a technical school, which was in 1892 taken over by the City Corporation. The College into which it has grown had in $192 \mathrm{I}-22$ an income of $\mathrm{I} 43,000 \mathrm{l}$., of which nearly 64 per cent. (more than the produce of a 4 d. rate) was provided by the Corporation. Of the 6223 students 553 were taking courses of university standard. An interesting series of articles upon the work and development of the College has been contributed to the Manchester City News by the former principal, Mr. J. H. Reynolds.

AMONG the various links connecting abstract science and engineering is the scientific education of engineers. Thirty years ago Sir William Anderson deplored the fact that except in the noble endowments of the City and Guilds schools and the Government institutions at South Kensington in London, the movement to secure the necessary training languished for want of adequate support. Sir Richard Glazebrook, in his "James Forrest" lecture to the Institution of Civil Engineers on May 4, made reference to this, and gave a brief outline of the conditions at present. The City and Guilds College -the Engineering Department of the Imperial College-opened in 1886 with 35 students; in July I922 there weie 492 engineering students in the College, and I 8 students of the Royal College of Science and the Royal School of Mines were also receiving instruction. The numbers for the Schools of the University of London and its other institutions were not quoted, but it may be said that these show corresponding increases. In the period from 1903 to 1922 London University conferred I294 internal and 756 external engineering degrees. The growth in the provincial universities and colleges has also been very large. Among other hopeful signs is the increasing interest in the education of apprentices shown by trades unions; a report on this subject was presented at the Trades Union Congress last year. The scheme of industrial bursaries started in IgI $x$ by the Royal Commission for the Exhibition of $185 \mathrm{I}$ is for the award of bursaries to students who have done well in some branch of science and who propose to go into works. Up to December last about $19,000 l$. has been expended on 185 bursars. The scheme is an extremely useful one and could be extended with advantage. Many young men find it extremely difficult, after a successful college career, to obtain adequate works experience without causing an intolerable drain on the slender resources of their parents. It is also of interest to record that there is an increasing demand by employers for collegetrained men; the associations of works and colleges were greatly strengthened during the War, and many firms now prefer men for their staffs who possess university degrees.

NO. 2795 , VOL. I I I] 